\title{
Analysis and Strategies of the Unbalance of the Supply and Demand in the Higher Education Market of China
}

\author{
Jie Ma \\ Normal College, Shihezi University, Shehezi 832003, China \\ E-mail: xiaojieruofeng@163.com
}

\begin{abstract}
The popularization of higher education largely impacts the balance of the supply and demand of the China higher education market. Starting from the basic concepts of the supply and demand of higher education, the actuality and influencing factors of the supply and demand in China higher education market are analyzed in this article, and corresponding advices and strategies about the sustainable development of Chinese colleges are proposed.
\end{abstract}

Keywords: Higher education of China, Conflict of supply and demand, Unbalance

Since the higher education of China entered into the stage of popularization, the higher education of China has been quickly developed, and whether the amount of colleges and schooling scale, or the schooling level all have been changed largely, but in the actuality and in the future, the conflict of the supply and demand in Chinese higher education market would still deeply influence the development of higher education. Therefore, it is very meaningful to discuss the unbalance of the supply and demand in Chinese higher education market and its influences, which will influence the survival and development of Chinese colleges.

The supply and demand of the higher education market includes the demand of higher education and the supply of higher education. The demand of higher education means the demand of the country, the society, and the individual for the payment ability of higher education. The supply of higher education means the education opportunities or education products that higher education institutions would and could offer under certain social conditions (Yang, 2004, P.54-56).

\section{Unbalanced representations of the supply and demand in China higher education market}

Under the situation of college graduates' employment marketization, the influence and limitation function of the market to higher education can not be ignored any more. The supply and demand in Chinese higher education market mainly represents the structured unbalance, and the conflict between the supply and the demand of the first higher education market gradually tends to decrease, but the conflict between the supply and the demand of the second higher education market is gradually increasing.

The conflict between the supply and the demand of the first higher education market is mainly represented by that the public's total demand to higher education exceeds the total supply of higher education to some extent. As seen in Figure 1, since China implemented the enrollment expansion in 1999, the enrollment number of Chinese colleges increases at the speed of about $20 \%$ each year. In 2002, the gross enrollment rate of Chinese higher education achieved $15 \%$, which indicated that China had formally entered into the popularization of higher education. In 2005, the gross enrollment rate of higher education was $21 \%$, and the scale of higher education had been the first position in the world. In 2006, this number ascended to $22 \%$ (Wang, 2007).

The "blowout" growth of talent supply in China could make for the accumulation of human capitals, the enhancement of employees' cultural and scientific quality, and the increase of the comprehensive strength, but on the other hand, the supply of Chinese labor force has exceeded the demand, and the yearly growth of the urban unit employment post amount supplied for college students has far lagged than the growth amount of graduates, which induces the situation of the supply and demand to be reversed. The former seller's market of higher education has completely turned into the buyer's market, so college students' difficult employments occur.

On the contrary, the conflict between the supply and the demand of the second higher education market is more and more drastic. The conflict is mainly represented by the conflict between the increases of the amount of college graduate with the deficient demand of the society to the graduates. After enrollment expansion, the talent supply ability of Chinese higher education is enhanced largely, and the amount of graduate increases year by year, but the employment rate of graduate reduces year by year (seen in Figure 3). According to the data of "China Labor Statistics Yearbook (2007)", there were about 1.2 million college students could not find a job in 2006, and in 2007, 1.4 million in 4.95 million graduates had not found a job, and in 2008, this number achieved 1.6 million. The "Social Blue Book (2008)" issued by Chinese Academy of Social Sciences showed that in near 
5 million college graduates in 2007, there were about 1 million graduates who had not find job up to now, and the employment situation of graduates is very inclement.

Figure 2 further indicated that the supply and demand conflict of the second market of Chinese higher education is that the supply far exceeds the demand, i.e. the one-time employment rates of graduates, undergraduates, and junior college students of Chinese general colleges present the descending tendency year by year, and the ratio has descended under $70 \%$ at present.

In summary, the unbalance of the supply and demand of Chinese higher education is represented in many aspects, and various unbalanced forms exist simultaneously, and the conflict is drastic. First, as viewed from the gross of supply and demand, on the one hand, China hopes that the amount entering into colleges would be more, i.e. the demand of the higher education service is quite flourishing, but the enrollment amount assumed by colleges is limited, so in the point of "service", the supply would restrain the gross of supply and demand of higher education. On the other hand, the amount of graduates in China each year is quite considerable, but the employment of these graduates is very difficult because of various reasons, so in the point of "product", the demand would restrain the gross of supply and demand of higher education. Second, as viewed from the supply and demand structure, individual and family orient the education intention to the hot specialties in the society because of various factors, and almost no one shows any interest in those cold specialties, so the enrollment number of hot specialties are more and more, but the enrollment amount is limited, and the supply is deficient. Though cold specialties have many enrollment indexes, students would not be interesting, and the demand is deficient. At present, various social and economic departments of China need more specially professional talents, but colleges have not cultivate sufficient talents for that, but provide large numerous professional talents that the demand is deficient, so the supply is surplus, and the demand is deficient. At present, the unbalance of supply and demand in Chinese higher education market is represented by the conflict and unification of the gross and structure that the supply restrains the supply and demand balance of higher education and the demand restrain the supply and demand balance.

\section{Causes of unbalanced development of the supply and demand in China higher education market}

The main cause of the unbalance of supply and demand in the second market is that the enrollment expansion policy in 1999 started from the economic development rule, not from the education development rule. Especially, the conflict that the supply exceeds the demand in the second market induced by the enrollment expansion of colleges has been the main conflict to impact the sustainable development of higher education.

\subsection{Disjointing between education structure and industry structure, employment market and talent demand}

First, the structured unbalance exists between the subject and the specialty. The higher education structure doesn't accord with the whole social and economic structure, especially with the industrial structure, which is the essential that the graduates of Chinese colleges present the instructed unbalance of employment. Because of the quick change of the social and economic structure, especially the industrial structure, the structure of Chinese higher education has not be adjusted in time, and its cultivated talents could not fulfill the demand of the society and the labor market well, and the conflict between the unemployment and the position opening. In recent years, the economy of China developed very quickly, but the college graduates who could adapt the development and research of Chinese resources are not sufficient, and the past junior college graduates and those students graduated from pure theory specialties are very abundant, so even the economy develops very quickly, the employment situation of local college students is not optimistic, so the employment situation of graduates is very grim.

Second, the structured unbalance exists in the education layers (Ma, 2006, P.72-107). In recent years, China gradually increases the power of the structure adjustment of higher education, but the layer structured conflict of the employment and the unbalanced phenomena of supply and demand still exist. As a whole, for graduates, the demand exceeds the supply; for undergraduates, the demand equals to the supply; for junior college students and higher vocational graduates, the supply obviously exceeds the demand.

\subsection{Disjointing between graduates' ability and social laborers' employment ability}

At present, fresh graduates' comprehensive quality and ability to adapt the society is deficient, which reflects that the quality education of colleges should be strengthened further. With the transformation of Chinese society to the market society, to pursue the economic benefit has become a core target of the whole society, and various employing units put talents' ability on the first position. Many employing units require talents to have professional knowledge and practical operation experiences. However, on the one hand, the education outlay of local colleges is often deficient, and the teaching experiment equipments and conditions can not fulfill the 
demand of the increase of student number well, and achieve the requirements of employing units; on the other hand, China higher education has entered into the stage of popularization, and the number of college students is more and more, and elites in he past has become the general students at this day, and whether for the acceptance ability of knowledge and technology, or the willpower of adapting the society and working hard, contemporary college students have not been compared with those elites, and many of them hankers after enjoyment and would not pay hard efforts, so the employment and the unemployment after employment are more and more grim.

\subsection{Graduates ' traditional employment concepts don't accord with actual employment forms}

According to some surveys, most graduates would be employed by public institutions, administrative institutions and big companies, not small-size private enterprises, and would go to big and middle cities, not rural regions, and countries. Many parents always hope their children to be managers and white collars, not technical works and blue collars. Many college graduates would rather stay at home than do the works which they think they should not do. In the economic transformation, the employment of college graduates is in the passive state, and many graduates have the idea to depend on others, and few of them would have the consciousness to active look for job or set up their own businesses, but the situation of the employment is grim now.

\section{Strategies to reduce the unbalance of the supply and demand in China higher education market}

As a whole, the conflict that the supply exceeds the demand in the second market of Chinese higher education has ascended to the main conflict. If this conflict continues, and many graduates can not be employed, not only large numerous education investments of the country and the public will be wasted, but with the gradual accumulation of graduates, the social stability will be certainly impacted, which goes against the country, the society, and the individual.

How to achieve the balance between the total demand and the total supply of higher education? Extending the supply and adjusting the demand are required. First, the government investment, civil investment and education consumers' investments should be increased, and the general higher education, private higher education, adult higher education, and vocational higher education should be developed largely to enhance the quality of education comprehensively. The modern information technology should be utilized to develop the remote education. The education system should be largely reformed to fully exert the function of existing education resources, and extend the supply to exceed the growth of demand and gradually reduce the conflict of demand and supply. Second, by pushing the higher education tuition marketization of higher education and reforming the educatee' tuition proportion, and increasing flow limitation of their payment ability, the growth of the total demand would be reduced, and the effective demand would be enhanced, and at the same time, the marketization would enhance the tuition of better colleges and correspondingly increase the investment in better higher education, so the supply will be increases to reduce the conflict between the supply and demand and selection (Wu, 2005, P.36-43).

\subsection{Changing traditional concepts and establishing the industrial view of higher education}

As viewed from the opinions of industrial economics and the attribute of education, the higher education is a special industry. Whether for the development function of education or for the product attribute of higher education, only to establish the industry view of higher education in modern society, the development of higher education could be better guided. The establishment of the higher education industry is to persist in "education is the industry of the production education service", "education is the industry to produce knowledge", "the investment of higher education possesses higher social and private yield", and "the quasi-public goods attribute of higher education products makes higher education to be a special industry". The practice has proved that only to change traditional concepts and establish the concept of higher education industry, could effectively grasp the development direction of higher education, and induce the attention of various governments and the public, and push the system innovation and the management system innovation, and manage the higher education by the idea of "industry", and promote the development of higher education balanced and healthy.

3.2 The schooling orientation of Chinese colleges should be oriented by the market and give prominence to the characteristic of talent cultivation

The general problem existing in China local colleges is that they have not feasible and practical schooling orientation, and they often blindly climb high target and tend to identification, break away from the demand of the market, lack in schooling characteristics and individuality, and the quality of talent cultivation is not high, which is the important cause that the talent cultivation can not adapt the market demand and the graduates' employment rate descends. The schooling orientation should be oriented by the market all along, i.e. colleges should grasp the market orientation at any time, and adjust the operation of various parts in time according to the 
supply and demand of the market and the demand of the society. Chinese colleges must take the market as the orientation to realize the multiform development and establish scientific and reasonable layer structure system of higher education, and part colleges should take the emphasis of teaching target on the guidance to cultivate complex and innovational talents with "width caliber, deep base, high quality and strong ability" who can adapt the requirement of the popularization. Aiming at this target, Chinese college could establish new course system, take the quality education as the core, set up more selected courses about skills, emphasize the cultivation of students' practice ability, ensure students more practice opportunities to make their theoretical knowledge to be utilized in practice effectively, strengthen students' instruction of employment and teach them to treat the employment by the popularized view. At the same time, only Chinese local colleges take the market demand as the orientation, adjust the specialty setting, confirm their service orientation and talent cultivation standard, and strengthen the practice teaching in the teaching, mainly cultivate students' hand skills and ability of solving practical problems to adapt the social demand to the largest extent, cultivate those talents who are welcomed by the market really, they can remain invincible in the future market competition.

\subsection{Chinese colleges should actively adjust the higher education structure to achieve the dynamic balance of the education structure with the industry structure and the employment structure}

First, Chinese colleges should actively adjust the higher education structure and largely develop the graduate education and the vocational higher education. At present, with the adjustment of industry structure, the employment structure of China presents that the first industry and the second industry proportion descend, and the third industry ascends stably, and the position of the fourth industry based on knowledge and information is continually ascending. Therefore, Chinese higher education must help graduates to turn to the third industry and the fourth industry by the adjustment of specialty and layer. Concretely, the structure adjustment of higher education subject specialty should not only aim at the requirements of relative key domains and the high new technical industry in future new economy, but face the talent cultivate of new technical industries needed in the present society, specially the cultivation of professional high-level talents and shortage talents with international competitive ability. Based on the stable scale of undergraduate education, the layer structure adjustment of higher education should largely develop the graduate education and the vocational technical education, and make the research talents, development talents and application talents to keep reasonable proportion structure to adapt the changing requirements of the society.

Second, Chinese colleges should actively adjust the regional structure of higher education, largely develop the rural community education, and expand the supply of higher education. Passing to villages is the necessary selection of Chinese higher education in the popularization times, and it is also the important measure to reduce the employment pressure in middle and big cities and fulfill the situation that many villages need more professional and technical talents. Rural community colleges could increase the investment, combine with many county resources such as technical secondary schools, TV universities, and party schools to enroll, cultivate, and employ students on the local places, which could not only reduce the shortage of education resources of higher education in the time of popularization, but reduce the large employment pressure.

Aiming at the actuality that the higher education market of China is not matured and various conflicts have not be disposed yet, to correctly utilize and operate the higher education market, and reasonably and optimally allocate the education resources according to the requirements of market economy could be propitious to liberate the educational productivity, promote the development of the higher education of China, fulfill the public's requirements for accepting the education with high quality and level, centralize the human capitals of China, and continually enhance the comprehensive strength and the core competitive force of China.

\section{References}

Deng, Guangping. (2004). Structural Unbalance of College Graduates' Employment and Over-education. Jiangsu Higher Education. No.3. P.42-45.

Liu, Wen. (2006). Study on the Higher Education Investment and Graduate Supply and Demand: Based on the View of Human Capital. Beijing: China Economy Press. P.101-125.

Ma, Yongxia. (2006). Conflict and Integration: Analysis of Supply and Demand Principals'Benefit of Higher Education. Beijing: Higher Education Press. P.72-107.

Wang, Feng. (2007). Higher Education: From Scale Expansion to Connotation Development. Social Science Weekly. May 10, 2007 (4).

Wu, Zejun. (2005). Supply and Demand Balance and Strategy Selection of Higher Education. Master's Thesis of Jiangxi Normal University. P.36-43. 
Yang, yang. (2004). Supply and Demand of Higher Education after Enrollment Expansion. Journal of Liaoning Institute of Technology (Social Science Edition). No.2(6). P.54-56.

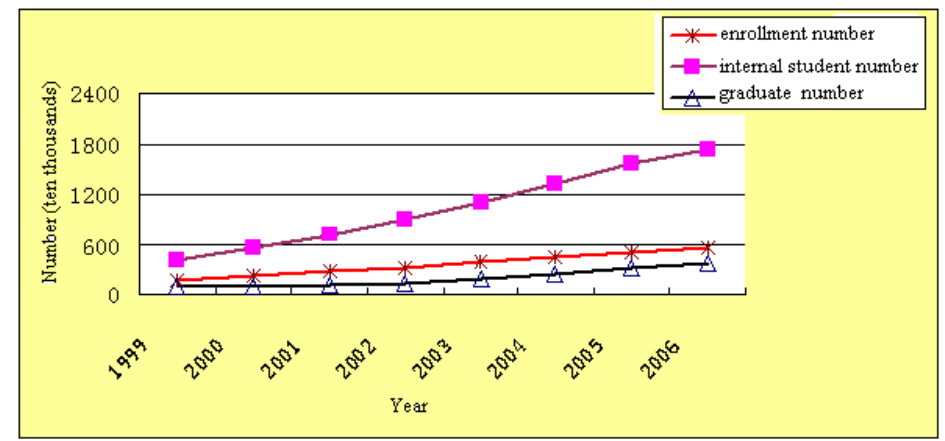

Figure 1. Supply and Demand Capacity of China General Colleges from 1999 to 2006

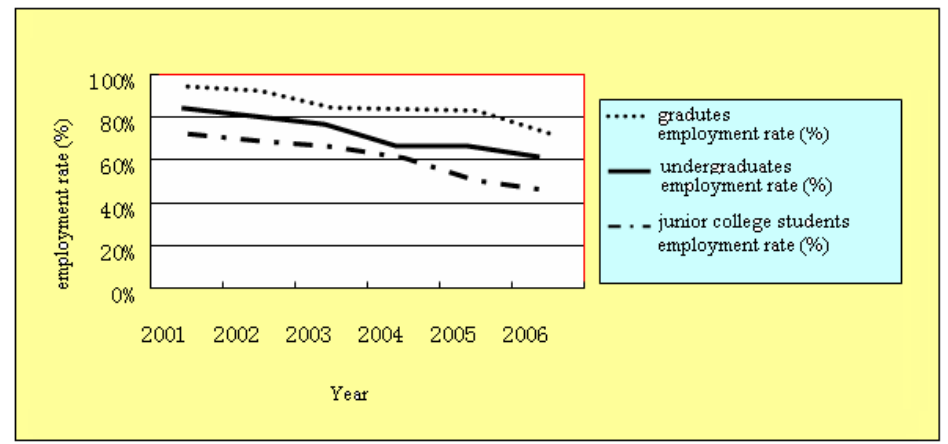

Figure 2. One-time Employment Rates of Graduates, Undergraduates, Junior College Students of China General Colleges from 1999 to 2006 (Data from: China Statistics Yearbook (2000-2007)) 